\title{
Morbidity Pattern of Hospital Admissions among Rural Adolescents
}

\author{
Dr.Syed Bahavudeen Hussaini ${ }^{1}$, Dr .P.S.Vallidevi ${ }^{2}$ \\ ${ }^{I}$ (Asst. Professor, Govt. Theni medical college Theni)' \\ ${ }^{2}$ (Asst. Professor, Govt. Theni medical college Theni)
}

\begin{abstract}
Introduction:WHO defined adolescents as people within the age group of 10-19 years. whether prejudice and discrimination will increase or decrease during adolescence will be greatly influenced by the environment in which adolescents find themselves and by the attitudes and behavior of their friends and associates. It is the period of heightening of all emotions like anxiety, fear, love, anger etc.

Aim of the study: To analyze the morbidity pattern for hospital admissions in Govt. Theni medical college, Theni, during the period January 2006 to December 2010.

Methods and materials: The study was conducted at Government Theni Medical College. Retrospective analysis of case records form January 2006 to December 2010

Results: $57.2 \%$ (4021) and 42.8\%(3006) represented male and female early adolescent admissions and $55.1 \%(8056)$ and $44.9 \%(6557)$ are male and female among late adolescent admissions. 924.8 (23\%) admissions were due to fever secondary to infections, 442.3 (11\%) accidental injury

Conclusion: In summary, most admissions in late adolescence were due to road traffic accidents, suicidal poisoning, for labour, and in early adolescence infections and accidental injuries were the reasons for admissions.. The scope for prevention and for ensuring the wellbeing of teenagers starts in childhood.
\end{abstract}

Keywords: (adolescence, morbidity, tertiary hospital)

\section{Introduction}

Adolescence is a critical period of human development manifested at the biological, psychological and social skills of interaction of variable onset and duration but marking the end of childhood and setting the foundation for maturity. WHO defined adolescents as people within the age group of 10-19 years. Whether prejudice and discrimination will increase or decrease during adolescence will be greatly influenced by the environment in which adolescents find themselves and by the attitudes and behavior of their friends and associates. It is a period of great stress and strain, storm and strife. Emotional development reaches its maximum or peak during adolescence. It is the period of heightening of all emotions like anxiety, fear, love, anger etc.

Aim of the study:

To analyze the morbidity pattern for hospital admissions in Govt. Theni medical college, Theni, during the period Januray2006 to December 2010.

\section{Methods and materials}

The study was conducted at Government Theni Medical College. Retrospective analysis of case records form January 2006 to December 2010 of General Medicine, Surgery, obstetrics and gynecology and pediatrics departments were done. Ethical clearance was obtained for collecting the data.

\section{Results}

Total adolescent admissions during the period was 21640(13\%) out of 154573 total hospital admissions. Adolescent deaths accounted for 5\% (144) among total hospital deaths of 2880 during the above said period. $32.5 \%$ (7027) accounted for young adolescent and 67.5\%(14613) for late adolescent admissions.

\begin{tabular}{|l|l|l|}
\hline DISEASE & MALE & FEMALE \\
\hline & $10-14$ YRS & $10-14$ YRS \\
\hline & Total no-4021 (\%) & Total no-3006 (\%) \\
\hline Fever due to Infections $^{1}$ & $924.8(23 \%)$ & $601.2(20 \%)$ \\
\hline Accidental injury & $442.3(11 \%)$ & $60.1(2 \%)$ \\
\hline Road traffic accidents & $402.1(11 \%)$ & $150.3(5 \%)$ \\
\hline Acute Gastritis & $361.9(9 \%)$ & $300.6(10 \%)$ \\
\hline Acute Diarrhoea $^{2}$ & $321.7(8 \%)$ & $360.7(12 \%)$ \\
\hline Bites $^{2}$ & $281.5(7 \%)$ & $180.4(6 \%)$ \\
\hline
\end{tabular}




\begin{tabular}{|l|l|l|}
\hline Suicidal poisoning & $281.5(7 \%)$ & $300.6(10 \%)$ \\
\hline Appendicitis & $241.3(6 \%)$ & $210.4(7 \%)$ \\
\hline Respiratory infections & $241.3(6 \%)$ & $270.5(9 \%)$ \\
\hline Seizure disorder & $120.6(3 \%)$ & $90.2(3 \%)$ \\
\hline Assault & $80.4(2 \%)$ & $60.1(2 \%)$ \\
\hline Hanging & $40.2(1 \%)$ & $60.1(2 \%)$ \\
\hline Phimosis & $40.2(1 \%)$ & $\infty \infty 000000000$ \\
\hline Burns & $40.2(1 \%)$ & $120.2(4 \%)$ \\
\hline anaemia & $\infty 00000000000$ & $60.1(2 \%)$ \\
\hline Others & $201.1(5 \%)$ & $180.4(6 \%)$ \\
\hline
\end{tabular}

${ }^{1}$ Fever due to infections includes infections due to viral, bacterial, parasitic involving any other organ other than respiratory system.

${ }^{2}$ Bites included snake, scorpion, unknown, human, wasp, bee sting and centipede.

$57.2 \%$ (4021) and $42.8 \%$ (3006) represented male and female early adolescent admissions and 55.1\%(8056) and $44.9 \%(6557)$ are male and female among late adolescent admissions

$924.8(23 \%)$ admissions were due to fever secondary to infections, $442.3(11 \%)$ accidental injury and 402.1 $(11 \%)$ road traffic accidents accounted for more number of admissions among male early adolescents.

601.2 (20\%) admissions were due to fever secondary to infections, 360.7 (12\%) Acute Diarrhea, $300.6(10 \%)$ Acute Gastritis, 300.6 (10\%) Suicidal poisoning accounted for more number of admissions among female early adolescents.

\begin{tabular}{|l|l|l|}
\hline DISEASE & MALE & FEMALE \\
\hline & $15-19$ YRS & $15-19$ YRS \\
\hline & Total no-8056 (\%) & Total no- $6557(\%)$ \\
\hline Road traffic accidents & $1772.3(22 \%)$ & $393.4(6 \%)$ \\
\hline Suicidal poisoning & $1450.1(18 \%)$ & $1180.2(18 \%)$ \\
\hline Accidental injury & $725.04(9 \%)$ & $262.3(4 \%)$ \\
\hline Bites $^{2}$ & $725.04(9 \%)$ & $393.4(6 \%)$ \\
\hline Assault & $644.5(8 \%)$ & $65.6(1 \%)$ \\
\hline Respiratory infections & $563.9(7 \%)$ & $131.1(2 \%)$ \\
\hline Acute Gastritis & $483.4(6 \%)$ & $262.3(4 \%)$ \\
\hline Fever due to Infections ${ }^{1}$ & $322.2(4 \%)$ & $327.6(5 \%)$ \\
\hline Acute Diarrhoea & $322.2(4 \%)$ & $524.6(8 \%)$ \\
\hline Appendicitis & $161.1(2 \%)$ & $262.3(4 \%)$ \\
\hline Seizure disorder & $161.1(2 \%)$ & $131.1(2 \%)$ \\
\hline Hanging & $80.6(1 \%)$ & $\infty 000000000000$ \\
\hline Burns & $80.6(1 \%)$ & $262.3(4 \%)$ \\
\hline Phimosis & $80.6(1 \%)$ & $\infty 00000000000$ \\
\hline Others & $563.9(7 \%)$ & $393.4(6 \%)$ \\
\hline For labour & $\infty 00000000000$ & $1836(28 \%)$ \\
\hline Anaemia & $\infty 000000000 \infty$ & $131.1(2 \%)$ \\
\hline & &
\end{tabular}

${ }^{1}$ Fever due to infections includes infections due to viral, bacterial, parasitic involving any other organ other than respiratory system.

${ }^{2}$ Bites included snake, scorpion, unknown, human, wasp, bee sting and centipede.

1772.3(22\%) admissions were due to Road traffic accidents, 1450.1(18\%) Suicidal poisoning, 725.04 (9\%) Accidental injury, 725.04 (9\%) Bites were common causes for late adolescent admissions in male. 1836 (28\%) admitted for labour, 1180.2 (18\%) for Suicidal poisoning, $524.6(8 \%)$ for Acute Diarrhea were common causes for late adolescent admissions in female.

\section{Discussion}

Teenagers are in transition between childhood and adulthood, and their increasing independence brings about new challenges and risks. This result in marked differences in patterns of morbidity and mortality for adolescents compared with younger children. They are more likely to engage in risky behaviors (such as substance use, dangerous driving and unsafe sexual practices), leading to high rates of violence and injury among young people. With reference to A Chakraborty et al [1] a higher proportion of male admissions $(60.2$ $\%)$ were noted. Systemic infections was the commonest cause of admission (33.6\%) which were in accordance with our study in early adolescent admission, and reasons for late adolescent admissions were in accordance with Sachdeva et al.[11] According to Australian institute of health and welfare 1 in 10 Australians aged 15-19 years reported a mental or behavioral problem. Reported prevalence and hospital bed day rate for mental and 
behavioral problems are each $40 \%$ higher among teenagers. Second most common cause for admission was Injury and poisoning [3] which is in accordance with our study.

The major causes of morbidity and mortality were infectious diseases with malaria and septicemia ranking highest, tetanus, Sickle cell anemia was the commonest disease [8]. Commonest (60\%) cause of admission was an infective cause (malaria, typhoid fever and septic arthritis) [9]. Head injury was the most common reason for hospital admission in males throughout the age range, admission rates increasing slightly in older adolescence. In girls, by the age of 15 years the most common reason for hospital admission was termination of pregnancy and other common reasons for hospital admission at 15 years were operations on tonsils and adenoids, appendicectomy, and poisoning[10]

\section{Conclusion}

In summary, most admissions in late adolescence were due to road traffic accidents, suicidal poisoning , for labour, and in early adolescence infections and accidental injuries were the reasons for admissions.. The scope for prevention and for ensuring the wellbeing of teenagers starts in childhood.

\section{References}

[1]. Morbidity Profile of Adolescents Admitted in a General Pediatric Ward,A Chakraborty, S Basu and B Rath Department of Pediatrics Lady Hardinge Medical College and Kalawati Saran Children's Hospital, New Delhi, India. Indian Pediatr 2015;52: 617618

[2]. Pattern and outcome of admissions at the children emergency room at the Federal Teaching Hospital Abakaliki- Onyinye U Anyanwu ${ }^{1}$, Obumneme B Ezeanosike ${ }^{2}$, Chinonyelu $\mathrm{T}$ Ezeonu ${ }^{2}$ Making progress: the health, development and wellbeing of australia's children and young people-Australian institute of health and welfare

[3]. James A, Clacey J, Seagroatt V, et al Adolescent inpatient psychiatric admission rates and subsequent one-year mortality in England: 1998-2004. J Child Psychol Psychiatry 2010;51:1395-404.

[4]. CDC National Health Report: Leading Causes of Morbidity and Mortality and Associated Behavioral Risk and Protective FactorsUnited States, 2005-2013

[5]. Trends in admissions, morbidity and outcomes at Red Cross War Memorial Children's Hospital, Cape Town, 2004 - 2013 Y IsaacsLong, L Myer, H J Zar -South African Medical Journal 2017;107(3):219-226. DOI:10.7196/SAMJ.2017.v107i3.11364

[6]. Morbidity pattern among the adolescent girls: A study in the social welfare hostels for scheduled castes, Nellore city, A.P., India.KM Susmitha, Jyothi C,Prabakaran J-Nat.J.Res.Com.Med .,1(1):01-60,2012

[7]. Adolescent morbidity and mortality pattern in an emergency paediatric unit in the federal capital territory, nigeria -Uduak Offiong,Felicia mairiga,paediatrics, university of abuja teaching hospital, Gwagwalada, Nigeria

[8]. Morbidity pattern and outcome of hospitalized adolescents in a tertiary rural hospital in north western nigeria-Umma Idris ,Bilya Rabiu paediatrics, Federal Medical Centre, paediatrics, federal medical centre birnin kudu, jigawa, Nigeria

[9]. Use of hospital inpatient care in adolescence-Jane Henderson, Michael Goldacre, David Yeates-Archives of Disease in Childhood 1993; 69: 559-563

[10]. Sachdeva S, Kapilashrami MC, Sachdev TR. Adolescent profile: hospital record based study. Int J Adolesc Med Health.2010;22:561-6 